Gulawentah: Jurnal Studi Sosial

Vol. 3, No. 1, Juni 2018, hal. 1-10

ISSN 2528-6293 (Print); ISSN 2528-6871 (Online)

Tersedia Online: http://e-journal.unipma.ac.id/index.php/gulawentah

\title{
Penggunaan Metode Take and Give untuk Meningkatkan Motivasi dan Prestasi Belajar Siswa pada Materi “Otonomi Daerah” SMP Negeri 3 Maospati Magetan
}

\author{
S. Suhadi \\ SMP Negeri 3 Maospati, Jl. Raya I/17 Maospati Kabupaten Magetan, Indonesia \\ Email: suhadi.sukomorodua@gmail.com
}

\begin{abstract}
Abstrak
Penelitian ini dilatarbelakangi oleh rendahnya prosentase ketercapaian atas Kriteria Ketuntasan Minimal (KKM) yang diperoleh siswa kelas IX H SMP Negeri 3 Maospati. Dari jumlah siswa 22 orang yang mengikuti post tes pada bahan ajar Otonomi Daerah dengan pembelajaran model Take and Give, hanya 3 orang yang dapat dinyatakan lulus (14\%) dan sisanya 19 orang dinyatakan belum lulus (86\%). Oleh karena itu, untuk kasus tersebut perlu diadakan remedial klasikal. Proses remedial klasikal dalam kasus ini penulis lakukan melalui kegiatan penelitian tindakan kelas. Penerapan metode take and give dapat meningkatkan motivasi dan prestasi belajar bidang studi PKn pada siswa kelas IX H SMP Negeri 3 Maospati. Dari aspek motivasi belajar siswa terjadi kenaikan dari siklus 1 ke siklus 2. Pada siklus 1 ratarata skor motivasi belajar siswa mencapai 57,4, sedangkan pada siklus 2 rata-rata skor motivasi belajar siswa mencapai 77. Nilai prestasi belajar siswa bisa dilihat dari hasil test yang dilakukan guru setelah selesai melaksanakan kegiatan belajar mengajar. Sebagai data awal atau prasiklus nilai rata-rata mencapai 57, kemudian siklus 1 mandapatkan nilai rata-rata 64. Pada siklus 2 nilai rata2 menacapai 78. Sedangkan data aktivitas guru menunjukkan ada kenaikan antara siklus 1 bila dibandingkan dengan siklus 2. Siklus 1 mendapat rata-rata skor 65 dan siklus 2 mendapat rata-rata skor 90 .
\end{abstract}

Kata kunci: metode take and give; prestasi belajar; motivasi belajar.

\section{The Use of Take and Give Method To Increase Students' Study Motivation and Achievement Territory Autonomy Material SMP Negeri 3 Maospati Magetan}

\begin{abstract}
This researsh is caused by low achievement percentage of minimal completeness criteria (MCC) that was got from class IX H students SMP Negeri 3 Maospati from 22 students who joined post test on Terytory Autonomy Material by using Take and Give learning method, only 3 students have passed (14\%) and 19 students haven't passed (86\%). Therefore, it need classical remidial. In classical remidial process, the writer does class action research activity. Take and Give method application can increase students' study motivation and achievement in PKn lesson class IX H SMP Negeri 3 Maospati. From students'study motivation there is an increase from first cycle to the second cycle. At the first cycle students' study motivation score average reaches 57,4 where as at the second cycle students study motivation score average reaches 77. Student study achievement mark can be see in the test mark that's done by teacher after teaching learning activities. As the early data or precycle, the average mark reaches 57, then in the first cycle the average mark reaches 64 . At the second cycle the average mark reaches 78 . Whereas teacher activities data shows an increase from first cycle to the second cycle. The first cycle's score average is 65 amd the second cycle's score average is 90.
\end{abstract}

Keywords: take and give method; study achievement; study motivation.

DOI: 10.25273/gulawentah.v3i1.2149

Copyright (C) 2018 Universitas PGRI Madiun

All rights reserved. 


\section{Pendahuluan}

Manusia membutuhkan ilmu dalam kehidupannya. Pendidikan merupakan usaha agar manusia dapat mengembangkan potensi dirinya melalui proses pembelajaran dan/atau cara lain yang dikenal dan diakui oleh masyarakat. Gerakan reformasi di Indonesia secara umum menuntut diterapkan prinsip demokrasi, desentralisasi, keadilan dan menjunjung tinggi hak asasi manusia dalam kehidupan berbangsa dan bernegara. Dalam hubungannya dengan pembelajaran, prinsip-prinsip tersebut akan memberikan dampak yang mendasar pada kandungan, proses dan manajemen sistem pembelajaran. Selain itu ilmu pengetahuan dan teknologi berkembang pesat dan memunculkan tuntutan baru dalam segala aspek kehidupan, termasuk dalam kegiatan belajar mengajar. Tuntutan tersebut menyangkut pembaharuan managemen pengajaran, diantaranya pembaharuan kurikulum, yaitu diversifikasi kurikulum untuk melayani peserta didik dan potensi daerah yang beragam, divertifikasi jenis pendidikan yang dilakukan secara profesional, penyusunan standart kompetensi tamatan yang berlaku secara nasional dan daerah menyesuaikan dengan kondisi setempat, penyusunan standar kualifikasi pendidik yang sesuai dengan tuntutan pelaksanaan tugas secara profesional, penyusunan standar pendanaan untuk setiap satuan pendidikan sesuai prinsip-prinsip pemerataan dan keadilan, pelaksanaan manajemen pendidikan berbasis sekolah, serta penyelenggaraan pendidikan dengan sistem terbuka dan multimakna. Pembaharuan sistem pendidikan juga meliputi penghapusan diskriminasi antara pendidikan yang dikelola pemerintah dengan swasta, serta pembedaan antara pendidikan agama dan pendidikan umum.

Gagasan mengenai peningkatan mutu pendidikan di Indonesia sebenarnya tidak pernah berhenti, terutama sejak berlakunya kurikulum sekolah sejak tahun 1975 . Kurikulum tersebut merupakan perbaikan kurikulum berbasis pengetahuan menjadi kurikulum berbasis kognitive. Kemudian pada tahun 1984, orientasi pendidikan yang berbasis kognitive disempurnakan menjadi berbasis keterampilan proses. Pada kurikulum 1994 penerapan pendidikan berbasis proses makin diintensifkan. Selanjutnya pada kurikulum 1999 muncul lagi gagasan pembaharuan dengan diperbaikinya konsep pendidikan berbasis kecakapan hidup dan berbasis kompetensi.

Banyak faktor yang dapat mempengaruhi keberhasilan implementasi kurikulum, beberapa faktor tersebut diantaranya menajemen lembaga pendidikan, peran guru, keaktifan siswa, proses belajar pengajar, sarana dan prasarana, penggunaan model dan metode mengajar dan lain-lain. Bila kita meninjau aktivitas kelas, maka guru adalah ujung tombak proses belajar mengajar. Seorang guru diharapkan memiliki kompetensi yang cukup sebagai pengelola pembelajaran, mampu menciptakan suasana dan lingkungan belajar yang efektif. Selain itu diharapkan terjadi suasana belajar yang dapat meningkatkan aktivitas, kreativitas, dan keaktifan siswa sebagai subjek belajar.

Mendidik adalah upaya mengembangkan potensi-potensi manusiawi peserta didik baik potensi fisik potensi cipta, rasa, maupun karsanya, agar potensi itu menjadi nyata dan dapat berfungsi dalam perjalanan hidupnya. Dasar mendidik adalah cita-cita kemanusiaan universal. Pendidikan bertujuan menyiapkan pribadi dalam keseimbangan, kesatuan. organis, harmonis, dinamis. guna mencapai tujuan hidup kemanusiaan. PKn seharusnya mampu mendidik siswa yang memiliki kepekaan sosial yang tinggi di masyarakat, rasa empati terhadap kehidupan sosial dan memiliki jiwa kepedulian sebagai anggota masyarakat, berbangsa atau bernegara. Tidak hanya menyampaikan setumpuk materi secara teori. Namun dari pengalaman empiris peneliti, saat ini masih banyak guru PKn yang mengajar sekedar menyampaikan materi, tanpa memperhatikan tujuan akhir dari pembelajaran PKn. Guru lebih suka menggunakan metode ceramah. Sehingga siswa 
kelihatan pasif, komunikasi hanya satu arah yaitu dari guru ke siswa. Tidak jarang pula guru sekedar memberikan catatan tanpa dibahas.

Hasil pengamatan peneliti sebelum mengadakan penelitian, aktivitas belajar siswa pada mata pelajaran PKn sangat rendah. Sebagian besar siswa nampak kurang memperhatikan selama mengikuti kegiatan belajar mengajar. Banyak yang berbicara dengan temannya, mengganggu temannya, bermain sendiri, bahkan ada yang tidur. Demikian juga dilihat dari prestasi siswa juga rendah. Dari KKM yang ditentukan sebesar 75, dari 24 siswa hanya 2 anak yang tuntas. Artinya hanya $8 \%$ yang tuntas, sedang $92 \%$ siswa belum tuntas. Ketuntasan belajar klasikal sebesar $8 \%$ ini masih sangat jauh dari yang ditentukan peneliti, dimana peneliti menentukan ketuntasan belajar secara klasikal sebesar $85 \%$. Untuk itu perlu dicari solusi alternatifnya. Satu diantaranya dengan menggunakan Metode Take and Give. Metode pembelajaran Take and Give. merupakan metode pembelajaran yang didukung oleh penyajian data yang diawali dengan pemberian kartu kepada siswa. Di dalam kartu, ada catatan yang harus dikuasai atau dihafal masingmasing siswa. Siswa kemudian mencari pasangannya masing-masing untuk bertukar pengetahuan sesuai dengan apa yang didapatnya di kartu, lalu kegiatan pembelajaran diakiri dengan mengevaluasi siswa dengan menanyakan pengetahuan yang mereka miliki dan pengetahuan yang mereka terima dari pasangannya.

Dengan demikian komponen penting dalam strategi Take and Give adalah penguasaan materi melalui kartu, ketrampilan bekerja berpasangan dan sharing informasi, serta evaluasi yang bertujuan untuk mengetahui pemahaman atau penguasaan siswa terhadap materi yang diberikan dalam kartu dan kartu pasangannya. Sintak langkahlangkah strategi pembelajaran Take and Give menurut Huda (2016:240) dapat dilihat sebagai berikut :

a. Guru mempersiapkan kartu yang akan digunakan dalam proses pembelajaran.

b. Guru mendesain kelas sebagaimana mestinya.

c. Guru menjelaskan materi sesuai dengan kompetensi yang ingin dicapai.

d. Untuk memantabkan penguasaan siswa, mereka diberi masing-masing satu kartu untuk dipelajarai atau dihafal.

e. Semua siswa disuruh berdiri dan mencari pasangan untuk saling memberi informasi. Tiap siswa harus mencatat nama pasangannya pada kartu yang dipegangnya.

f. Demikian seterusnya hingga setiap siswa dapat saling memberi dan menerima materi masing-masing.

g. Untuk mengevaluasi keberhasilan siswa, guru dianjurkan memberi pertanyaan yang tidak sesuai dengan kartu.

h. Strategi ini dapat dimodifikasi sesuai dengan keadaan.

i. Guru menutup pembelajaran.

Ada beberapa pendapat yang memberi pengertian dari prestasi dan pengertian belajar. Kamus Besar Bahasa Indonesia Depdiknas edisi ketiga, (2002; 895) menyebutkan bahwa prestasi adalah hasil yang telah dicapai dari yang telah dilakukan, dikerjakan. Hal serupa disampaikan Winkel (dalam Suryabrata, 2003:161) menyebutkan prestasi adalah bukti usaha yang dapat dicapai. Pendapat-pendapat memaknai prestasi itu merupakan hasil yang diperoleh dari proses belajar. Belajar adalah suatu proses usaha yang dilakukan individu untuk memperoleh suatu perubahan tingkah laku secara keseluruhan, sebagai hasil pengalaman individu itu sendiri dalam interaksi dengan lingkungannya (Slameto, 2003). Sudjana (2011:17) juga menyampaikan bahwa belajar merupakan suatu proses yang ditandai dengan adanya perubahan pada diri seseorang. 
Hasil belajar berkaitan juga dengan motivasi belajar. Motivasi belajar merupakan dorongan yang timbul pada diri seseorang secara sadar atau tidak sadar untuk melakukan sesuatu tindakan dengan tujuan tertentu (Tim Bahasa Depdikbud, 2007). Hal ini sejalan dengan pendapat Sardiman (2012) bahwa belajar sangat diperlukan adanya motivasi. Adapub fungsi motivasi belajar yaitu:

a. Mendorong manusia untuk berbuat, jadi sebagai penggerak atau motor yang melepaskan energi. Motivasi dalam hal ini merupakan motor penggerak dari setiap kegiatan yang akan dikerjakan.

b. Menentukan arah perbuatan, yakni kearah tujuan yang hendak dicapai. Dengan demikian motivasi dapat memberikan arah dan kegiatan yang harus dikerjakan sesuai dengan rumusan tujuan.

c. Menyeleksi perbuatan, yakni menentukan perbuatan-perbuatan apa yang harus dikerjakan guna mencapai tujuan, dengan menyisihkan perbuatan-perbuatan yang tidak bermanfaat bagi tujuan tersebut. Seseorang siswa yang akan menghadapi tujuan dengan harapan dapat lulus, tentu akan melakukan kegiatan belajar dan tidak akan menghabiskan waktu untuk bermain kartu atau membaca komik, sebab tidak sesuai dengan tujuan.

\section{Metode Penelitian}

Penelitian ini menggunakan pendekatan kualitatif dan jenis penelitiannya tindakan kelas. Penelitian dilaksanakan dalam satu semester pada tahun pelajaran 2017/2018. Subyek penelitian ini yaitu siswa kelas IX SMP Negeri 3 Maospati Magetan yang berjumlah 24 anak. Teknik pengumpulan data yang digunakan yaitu teknik observasi dan tes hasil belajar. Sedangkan data hasil belajar siswa setelah dilakukan koreksi dan scoring akan dianalisa berdasarkan kreteria ketuntasan belajar (mastery learning) yakni $85 \%$ dari jumlah siswa yang telah mencapai $75 \%$ taraf penguasaan materi yang diberikan (KKM 75). Penelitian tindakan kelas ini berkolaborator dengan seorang guru SMP Negeri 3 Maospati dengan menggunakan sistem siklus dengan skema sebagaimana bagan di bawah ini:

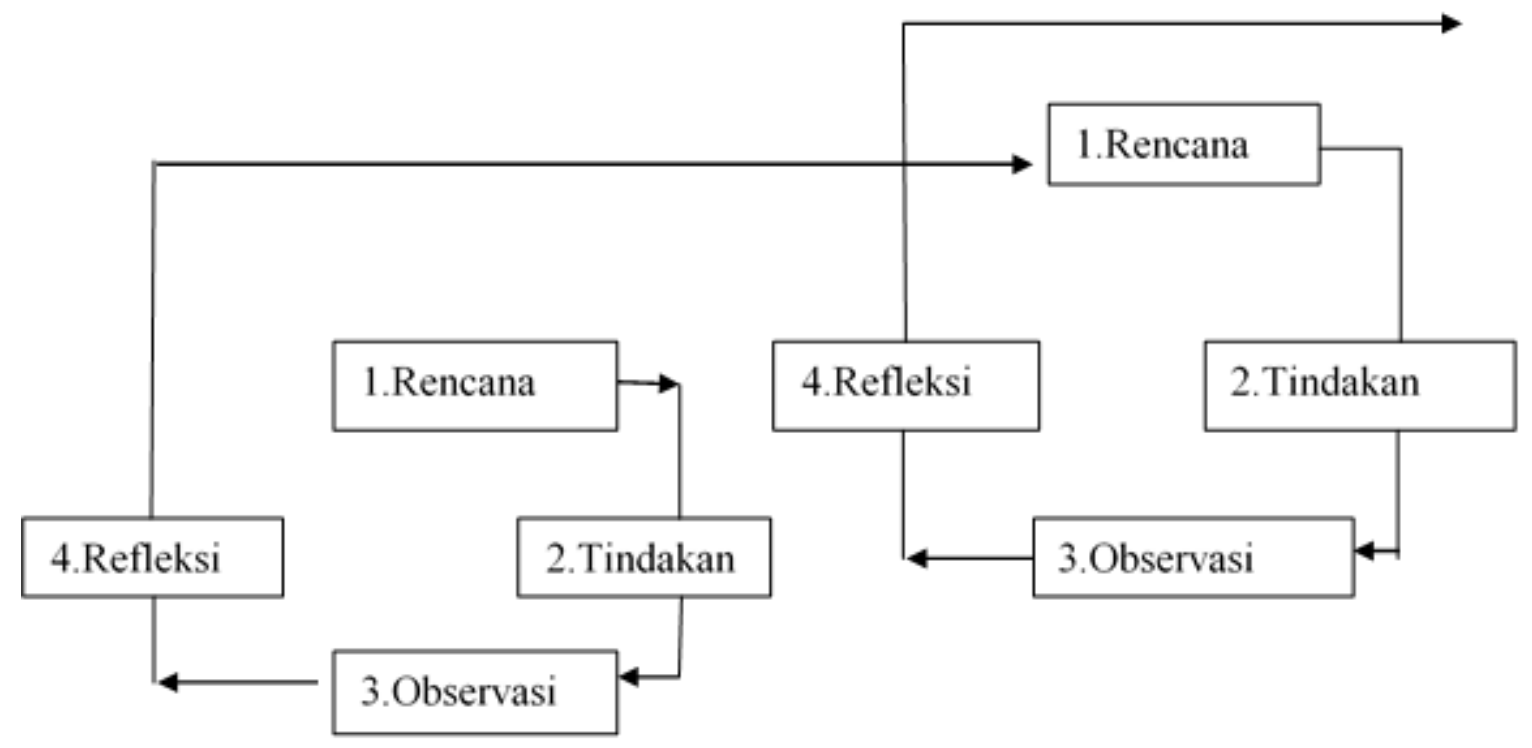

Gambar 1. Skema penelitian tindakan kelas (Mulyasa, 2010:73) 


\section{Hasil dan Pembahasan}

\section{Siklus Pertama}

Prestasi belajar dan motivasi belajar siswa kelas IX SMP Negeri Maospati Magetan setelah diberi perlakuan dengan menggunakan metode take and give mengalami peningkatan dibandingkan dengan hasil belajar sebelumnya atau prasiklus. Hal ini dapat dilihat pada tabel 1 dan tabel 2.

Tabel 1. Prestasi Belajar Pendidikan Kewarganegaraan Siswa Pada Siklus 1

\begin{tabular}{clcc}
\hline No & \multicolumn{1}{c}{ Nama } & Nilai & Keterangan \\
\hline 1 & Eka Lestari & 75 & Tuntas \\
\hline 2 & Eka Puspita Sari & 70 & Remidi \\
\hline 3 & Erly Hermawati W.P. & 65 & Remidi \\
\hline 4 & Fandi Wahyu K. & 60 & Remidi \\
\hline 5 & Gandhi Arya N. & 45 & Remidi \\
\hline 6 & Lamita & 75 & Tuntas \\
\hline 7 & Lucky Nurjanah & 70 & Remidi \\
\hline 8 & Lusi Ika Prasasti & 70 & Remidi \\
\hline 9 & Miftakul Aziz & 55 & Remidi \\
\hline 10 & Muhammad Aldo S. & 55 & Remidi \\
\hline 11 & Muhammad Ardiyansah & 65 & Remidi \\
\hline 12 & Nicky Larasati & 55 & Remidi \\
\hline 13 & Nika Septiana I. & 70 & Remidi \\
\hline 14 & Novia Kurnia S. & 80 & Tuntas \\
\hline 15 & Reza Prasetyo & 65 & Remidi \\
\hline 16 & Sakti Pradana P. & 65 & Remidi \\
\hline 17 & Sella Silvi R. & 60 & Remidi \\
\hline 18 & Tia Rahmawati & 75 & Tuntas \\
\hline 19 & Wahyu Akhbar I. & 50 & Remidi \\
\hline 20 & Yudi Aditama & 60 & Remidi \\
\hline 21 & Yuna Febrian G. & 50 & Remidi \\
\hline 22 & Yunita Dwi A. & 75 & Tuntas \\
\hline 23 & Yusuf Dwi S. & 60 & Remidi \\
\hline 24 & Raihan Aldai P.W. & 70 & Remidi \\
\hline & Jumlah & Rata-rata & \\
\hline & & 640 & \\
\hline & & \\
\hline
\end{tabular}


Tabel 2. Motivasi Belajar Pendidikan Kewarganegaraan Siswa Pada Siklus 1

\begin{tabular}{|c|c|c|c|c|c|c|c|c|}
\hline \multirow{2}{*}{ No } & \multirow{2}{*}{ Nama } & \multicolumn{5}{|c|}{ Unsur Pengamatan } & \multirow{2}{*}{ Jumlah } & \multirow{2}{*}{ Rata- rata } \\
\hline & & 1 & 2 & 3 & 4 & 5 & & \\
\hline 1 & Eka Lestari & 3 & 3 & 2 & 2 & 2 & 12 & 2.40 \\
\hline 2 & Eka Puspita Sari & 2 & 2 & 2 & 3 & 3 & 12 & 2.40 \\
\hline 3 & Erly Hermawati W.P. & 2 & 2 & 2 & 3 & 2 & 11 & 2.20 \\
\hline 4 & Fandi Wahyu K. & 2 & 2 & 2 & 2 & 2 & 10 & 2.00 \\
\hline 5 & Gandhi Arya N. & 3 & 3 & 2 & 3 & 2 & 13 & 2.60 \\
\hline 6 & Lamita & 2 & 2 & 2 & 2 & 2 & 10 & 2.00 \\
\hline 7 & Lucky Nurjanah & 3 & 3 & 2 & 3 & 3 & 14 & 2.80 \\
\hline 8 & Lusi Ika Prasasti & 2 & 1 & 2 & 2 & 3 & 10 & 2.00 \\
\hline 9 & Miftakul Aziz & 1 & 3 & 2 & 3 & 2 & 11 & 2.20 \\
\hline 10 & Muhammad Aldo S. & 2 & 3 & 2 & 3 & 2 & 12 & 2.40 \\
\hline 11 & Muhammad Ardiyansah & 3 & 2 & 3 & 2 & 3 & 13 & 2.60 \\
\hline 12 & Nicky Larasati & 2 & 3 & 3 & 2 & 3 & 13 & 2.60 \\
\hline 13 & Nika Septiana I. & 2 & 2 & 1 & 2 & 2 & 9 & 1.80 \\
\hline 14 & Novia Kurnia S. & 3 & 1 & 3 & 1 & 2 & 10 & 2.00 \\
\hline 15 & Reza Prasetyo & 2 & 2 & 3 & 3 & 3 & 13 & 2.60 \\
\hline 16 & Sakti Pradana P. & 1 & 3 & 2 & 3 & 2 & 11 & 2.20 \\
\hline 17 & Sella Silvi R. & 2 & 3 & 2 & 3 & 1 & 11 & 2.20 \\
\hline 18 & Tia Rahmawati & 2 & 2 & 3 & 2 & 2 & 11 & 2.20 \\
\hline 19 & Wahyu Akhbar I. & 3 & 3 & 2 & 3 & 3 & 14 & 2.80 \\
\hline 20 & Yudi Aditama & 2 & 1 & 2 & 2 & 3 & 10 & 2.00 \\
\hline 21 & Yuna Febrian G. & 1 & 2 & 3 & 1 & 2 & 9 & 1,80 \\
\hline 22 & Yunita Dwi A. & 2 & 3 & 2 & 2 & 3 & 12 & 2.40 \\
\hline 23 & Yusuf Dwi S. & 3 & 2 & 2 & 3 & 2 & 12 & 2.40 \\
\hline \multirow[t]{3}{*}{24} & Raihan Aldai P.W. & 3 & 3 & 3 & 3 & 2 & 14 & 2.80 \\
\hline & Jumlah & 53 & 56 & 54 & 58 & 56 & 277 & 55,4 \\
\hline & Skor & 55 & 58 & 56 & 60 & 58 & 287 & 57,4 \\
\hline
\end{tabular}

Keterangan

1. Memperhatikan/mendengarkan penjelasan guru

2. Mengerjakan tugas

3. Diskusi antar teman

4. Mengumpulakan tugas

5. Keaktifan

Data dari tabel di atas menunjukkan bahwa skor rata-rata aktivitas yang menunjukkan motivasi belajar siswa terhadap kegiatan belajar mengajar pada siklus 1 adalah 57,4 yang berarti masih kategori kurang. Hasil analisis pada siklus I adalah proses kegiatan belajar mengajar tidak seperti yang diharapkan. Hal ini disebabkan oleh beberapa hal, yaitu:

1) Peserta didik masih bingung dengan metode take and give karena selama ini belum terbiasa digunakan dalam kegiatan belajar mengajar. 
2) Alokasi waktu dalam kegiatan belajar mengajar belum diatur dengan baik, sehingga masih banyak anak yang belum selesai memberi serta menerima informasi dari temannya.

3) Tidak ada sarana dan prasarana penunjang lain seperti buku paket penunjang yang sesuai sehingga kesiapan siswa kurang baik.

4) Perlu ada morivasi kepada siswa untuk lebih maksimal dalam mengikuti kegiatan belajar mengajar.

\section{Siklus Kedua}

Prestasi belajar dan motivasi belajar siswa kelas IX SMP Negeri Maospati Magetan setelah diberi perlakuan dengan menggunakan metode take and give mengalami peningkatan dibandingkan dengan hasil belajar dan motivasi sebelumnya atau siklus 1 . Hal ini dapat dilihat pada tabel-tabel di bawah ini

Tabel 3. Prestasi Belajar Pendidikan Kewarganegaraan Siswa Pada Siklus 2

\begin{tabular}{|c|c|c|c|}
\hline No & Nama & Nilai & Keterangan \\
\hline 1 & Eka Lestari & 80 & Tuntas \\
\hline 2 & Eka Puspita Sari & 80 & Tuntas \\
\hline 3 & Erly Hermawati W.P. & 80 & Tuntas \\
\hline 4 & Fandi Wahyu K. & 75 & Tuntas \\
\hline 5 & Gandhi Arya N. & 70 & Remidi \\
\hline 6 & Lamita & 85 & Tuntas \\
\hline 7 & Lucky Nurjanah & 75 & Tuntas \\
\hline 8 & Lusi Ika Prasasti & 80 & Tuntas \\
\hline 9 & Miftakul Aziz & 75 & Tuntas \\
\hline 10 & Muhammad Aldo S. & 75 & Tuntas \\
\hline 11 & Muhammad Ardiyansah & 75 & Tuntas \\
\hline 12 & Nicky Larasati & 75 & Tuntas \\
\hline 13 & Nika Septiana I. & 75 & Tuntas \\
\hline 14 & Novia Kurnia S. & 90 & Tuntas \\
\hline 15 & Reza Prasetyo & 75 & Tuntas \\
\hline 16 & Sakti Pradana P. & 75 & Tuntas \\
\hline 17 & Sella Silvi R. & 80 & Tuntas \\
\hline 18 & Tia Rahmawati & 80 & Tuntas \\
\hline 19 & Wahyu Akhbar I. & 85 & Tuntas \\
\hline 20 & Yudi Aditama & 75 & Tuntas \\
\hline 21 & Yuna Febrian G. & 75 & Tuntas \\
\hline 22 & Yunita Dwi A. & 85 & Tuntas \\
\hline 23 & Yusuf Dwi S. & 80 & Tuntas \\
\hline \multirow[t]{3}{*}{24} & Raihan Aldai P.W. & 80 & Tuntas \\
\hline & Jumlah & 1.880 & Tuntas \\
\hline & Rata-rata & 78 & \\
\hline
\end{tabular}


Tabel 4. Motivasi Belajar Pendidikan Kewarganegaraan Siswa Pada Siklus 1

\begin{tabular}{|c|c|c|c|c|c|c|c|c|}
\hline \multirow{2}{*}{ No } & \multirow{2}{*}{ Nama } & \multicolumn{5}{|c|}{ Unsur Pengamatan } & \multirow{2}{*}{ Jumlah } & \multirow{2}{*}{ Rata- rata } \\
\hline & & 1 & 2 & 3 & 4 & 5 & & \\
\hline 1 & Eka Lestari & 4 & 3 & 3 & 4 & 3 & 17 & 3.40 \\
\hline 2 & Eka Puspita Sari & 3 & 3 & 3 & 3 & 4 & 16 & 3.20 \\
\hline 3 & Erly Hermawati W.P. & 2 & 4 & 2 & 4 & 3 & 15 & 3.00 \\
\hline 4 & Fandi Wahyu K. & 3 & 2 & 4 & 3 & 2 & 14 & 2.80 \\
\hline 5 & Gandhi Arya N. & 4 & 4 & 3 & 3 & 4 & 18 & 3.60 \\
\hline 6 & Lamita & 2 & 3 & 3 & 3 & 3 & 14 & 2.80 \\
\hline 7 & Lucky Nurjanah & 4 & 3 & 4 & 4 & 4 & 19 & 3.80 \\
\hline 8 & Lusi Ika Prasasti & 3 & 2 & 2 & 2 & 4 & 13 & 2.60 \\
\hline 9 & Miftakul Aziz & 2 & 4 & 3 & 4 & 2 & 15 & 3.00 \\
\hline 10 & Muhammad Aldo S. & 2 & 3 & 3 & 3 & 3 & 14 & 2.80 \\
\hline 11 & Muhammad Ardiyansah & 4 & 3 & 4 & 4 & 4 & 19 & 3.80 \\
\hline 12 & Nicky Larasati & 3 & 4 & 4 & 3 & 3 & 17 & 3.40 \\
\hline 13 & Nika Septiana I. & 2 & 2 & 2 & 3 & 4 & 13 & 2.60 \\
\hline 14 & Novia Kurnia S. & 4 & 3 & 3 & 3 & 2 & 15 & 3.00 \\
\hline 15 & Reza Prasetyo & 3 & 2 & 4 & 4 & 4 & 17 & 3.40 \\
\hline 16 & Sakti Pradana P. & 2 & 4 & 2 & 4 & 3 & 15 & 3.00 \\
\hline 17 & Sella Silvi R. & 3 & 3 & 3 & 3 & 2 & 14 & 2.80 \\
\hline 18 & Tia Rahmawati & 4 & 3 & 4 & 3 & 2 & 16 & 3.20 \\
\hline 19 & Wahyu Akhbar I. & 4 & 4 & 2 & 4 & 4 & 18 & 3.60 \\
\hline 20 & Yudi Aditama & 3 & 3 & 3 & 2 & 3 & 14 & 2.80 \\
\hline 21 & Yuna Febrian G. & 2 & 2 & 4 & 2 & 3 & 13 & 2.60 \\
\hline 22 & Yunita Dwi A. & 3 & 4 & 3 & 3 & 4 & 17 & 3.40 \\
\hline 23 & Yusuf Dwi S. & 4 & 3 & 4 & 4 & 3 & 18 & 3.60 \\
\hline 24 & Raihan Aldai P.W. & 4 & 4 & 3 & 4 & 3 & 18 & 3.60 \\
\hline & Jumlah & 74 & 74 & 74 & 74 & 74 & 370 & 74,0 \\
\hline & Skor & 77 & 77 & 77 & 77 & 77 & 386 & 77 \\
\hline
\end{tabular}

Dari tabel 3 di atas dapat diketahui bahwa pada siklus 2 target yang ditetapkan telah tercapai baik nilai maupun jumlah siswa yang tuntas:

Rata-rata $=\frac{1.880}{24}=78$

Sedangkan prosentase ketuntasan belajar

Ketuntasan $\frac{23}{24} \times 100=96 \%$

Sedangkan motivasi siswa dalam mengikuti pembelajaran pada siklus 2 sebesar 77. Dengan demikian masuk kategori baik. Pada siklus II proses kegiatan belajar mengajar sudah lebih baik dari siklus I hal ini disebabkan kelemahan-kelemahan pada siklus I sudah diperbaiki antara lain :

1) Guru sudah memberikan penjelasan secara detail tahapan menggunakan metode take and give dalam pembelajaran.

2) Guru sudah mengatur penggunaan waktu secara ketat, sehingga semua siswa sudah saling memberi dan menerima informasi. 
3) Guru memberikan motivasi kepada siswa dengan memberikan hadiah bagi siswa yang sudah menerima semua informasi dari temannya.

Berdasarkan hasil penilaian dan pengamatan siswa guru menunjukkan bahwa dengan menggunakan take and give dapat membantu siswa dalam meningkatkan memahami pelajaran Pendidikan Kewarganegaraan (PKn) pada standar kompetensi pelaksanaan Otonomi Daerah

Data perbandingan nilai rata-rata hasil tes siswa setiap siklus bisa digambarkan dalam tabel berikut:

Tabel 5. Perbandingan Rata-rata Nilai

\begin{tabular}{cccc}
\hline Kelas & Pra Siklus & Siklus I & Siklus II \\
\hline IX H & 57 & 64 & 78 \\
\hline
\end{tabular}

Dari data perbandingan nilai rata-rata hasil tes tersebut dapat dibuat grafik sebagai berikut:

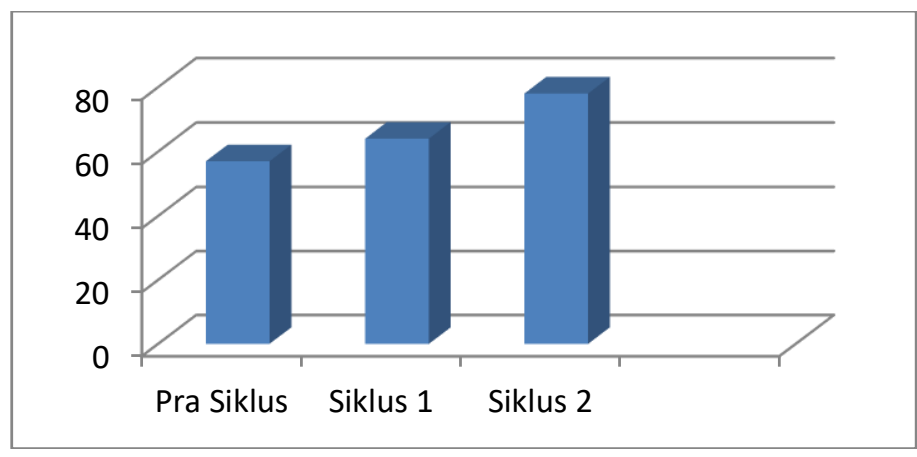

Gambar 2. Perbandingan nilai rata-rata

Demikian juga terkait dengan prosentase ketuntasan antar siklus menunjukkan adanya kenaikan. Hal ini bisa dilihat pada tabel 6 sebagai berikut:

Tabel 6. Perbandingan Ketuntasan Belajar

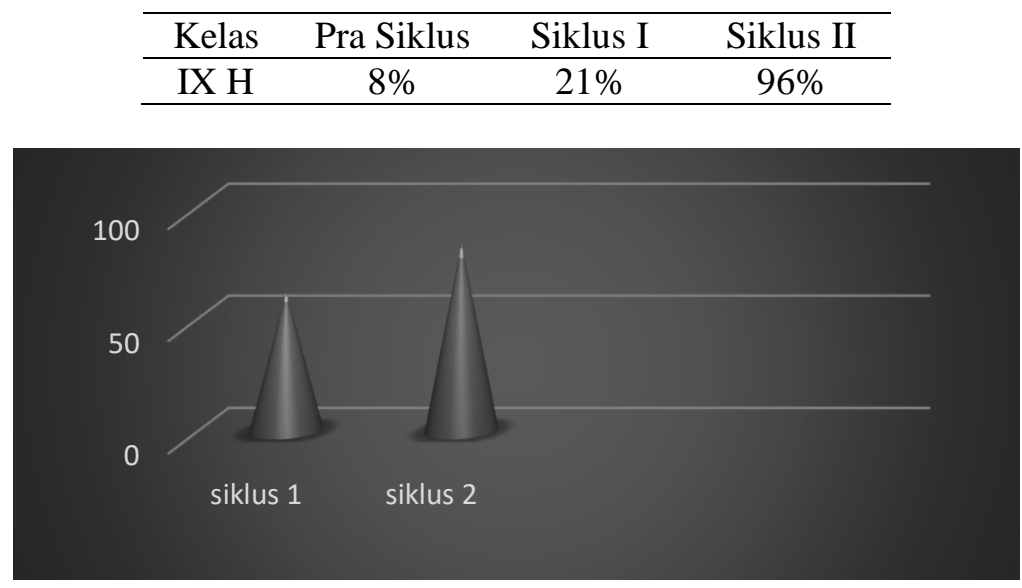

Gambar 3. Kenaikan rata-rata motivasi belajar

Dari aspek motivasi belajar siswa terjadi kenaikan dari siklus 1 ke siklus 2. Pada siklus 1 rata-rata skor motivasi belajar siswa mencapai 57,4, sedangkan pada siklus 2 rata- 
rata skor motivasi belajar siswa mencapai 77 . Data kenaikan skor rata-rata motivasi belajar siswa antarsiklus dapat digambarkan seperti gambar 3.

\section{Kesimpulan}

Berdasarkan hasil pengamatan aktivitas dan perolehan hasil belajar siswa selama 2 siklus, diperoleh simpulan bahwa penggunaan metode take and give dapat meningkatkan motivasi dan prestasi belajar bidang studi PKn pada siswa kelas IX H SMP Negeri 3 Maospati. Dari aspek motivasi belajar siswa terjadi kenaikan dari siklus 1 ke siklus 2. Pada siklus 1 rata-rata skor motivasi belajar siswa mencapai 57,4, sedangkan pada siklus 2 rata-rata skor motivasi belajar siswa mencapai 77 . Nilai prestasi belajar siswa bisa dilihat dari hasil test yang dilakukan guru setelah selesai melaksanakan kegiatan belajar mengajar. Sebagai data awal atau prasiklus nilai rata-rata mencapai 57, kemudian siklus 1 mandapatkan nilai rata-rata 64. Pada siklus 2 nilai rata2 menacapai 78. Sedangkan data aktivitas guru menunjukkan ada kenaikan antara siklus 1 bila dibandingkan dengan siklus 2. Siklus 1 mendapat rata-rata skor 65. Siklus 2 mendapat rata-rata skor 90 .

\section{DAFTAR PUSTAKA}

Huda, M. (2013). Cooperative Learning Metode, Tehnik, Strukturdan Model Terapan. Yogyakarta: Pustaka Pelajar.

Huda, M. (2016). Model-Model Pengajaran dan Pembelajaran. Yogyakarta: Pustaka Pelajar.

Mulyasa. (2010). Praktik Penelitian Tindakan Kelas. Bandung: PT Remaja Rosdakarya

Sardiman. (2012).Interaksi dan Motivasi Belajar-Mengajar.Depok: PT Rajagrafindo Persada.

Slameto.(2003). Belajar dan Faktor-Faktor Yang Mempengaruhinya. Jakarta: Rineka Cipta

Sudjana, N. (2011). Dasar-dasar Proses Belajar Mengajar. Bandung: Sinar Baru Algesindo

Suryabrata, S.(2013). Psikologi Pendidikan. Jakarta: Raja Grafindo.

Tim Bahasa Depdikbud. (2007). Kamus Besar Bahasa Indonesia.Jakarta: Balai Pustaka

Trianto. (2009). Mendesain Model Pembelajaran Inovatif Progresif: Konsep, Landasan, dan Implementasinya Pada Kurikulum Tingkat Satuan Pendidikan. Jakarta: Kencana Prenada Media Group 